PROBLEMS

OF EDUCATION IN THE $21^{\text {st }}$ CENTURY Vol. 80 , No. 1, 2022

144

\title{
PRE-SERVICE TEACHERs' APPROACHES TO GUIDING STUDENTS IN PROBLEM SOLVING PROCESS
}

\author{
Fatma Cumhur \\ Muş Alparslan University, Turkey \\ E-mail: cumhurfatma@gmail.com
}

\begin{abstract}
Understanding students' mathematical thinking in problem solving process plays an important role in facilitating the solution. Hence, teachers or pre-service teachers need to understand students' thoughts and guide them to the correct answer. The aim of this study was to examine pre-service teachers' approaches to guiding students in problem solving process. Designed as a case study, this study was carried out with five pre-service primary mathematics teachers. In the study, participants' dialogues with $7^{\text {th }}$ grade students were examined through 3 non-routine problems. The dialogues were transcribed and it was tried to reveal what kind of approaches the participants displayed. The content analysis was used in data analysis. The findings revealed that pre-service teachers followed Polya's problem-solving steps during their guiding approaches. Most pre-service teachers provided appropriate guidance in understanding the problem, selecting and implementing appropriate strategies for the problem; however, they failed to use the evaluative approaches sufficiently.
\end{abstract}

Keywords: guiding approaches, multiple case study, pre-service teacher, problem-solving

\section{Introduction}

A problem is defined, mathematically, as an issue that cannot be solved at first glance (Jonassen, 2000). In terms of teaching, a problem refers to an interesting question for which students do not know the solution, but have some preliminary information for the solution (Schoenfeld, 1989). In this respect, problem solving plays an important role in understanding mathematical knowledge and developing the relationship between this knowledge (Peterson, 1988). Problem solving is a crucial part of mathematics education and has a significant place in the curriculum. Basically, problem-solving is a learning process that reinforces, broadens, and deepens mathematical knowledge through the use of prior knowledge and experience. In this sense, Polya (1997) defines problem solving as a deliberate search for actions that can be taken to achieve the goal in the most reasonable way. Therefore, problem solving is not simply finding the result, but confronting new situations and producing creative solutions to these situations. Swing and et al. (1988) state that problem-solving is important in understanding mathematical knowledge and developing the relationship between this knowledge since the teachers' answers to students' thoughts help students to construct their reasoning and knowledge (Even \& Markovits, 1995).

Problem-solving has an important role in questioning students' mathematical knowledge. It consists of vital cognitive processes such as understanding the sentence, selecting the necessary data for the solution, answering the problem, and deciding whether or not the answer makes sense (Baki, 2006). Considering that problem-solving is a mathematical activity process including many cognitive processes, it can be argued that the teacher has important responsibilities in this process. In this sense, teachers and pre-service teachers are expected to have strong pedagogical knowledge about guiding students in problem-solving process (Biber et al., 2017). The need for teachers to understand students' thinking about mathematical concepts 
PROBLEMS

OF EDUCATION

IN THE $21^{\text {st }}$ CENTURY

Vol. 80 , No. 1,2022

have been recognized as a teacher competency for a long time (National Council of Teachers of Mathematics- NCTM, 2000). In recent years, numerous studies on student thinking have emphasized the strong pedagogical knowledge of the teacher (Didiş et al., 2016; Wilson and et al., 2013) due to the fact that understanding and interpreting students' mathematical thoughts ensures an effective delivery of teaching activities (Carpenter et al., 1989; Roberts, 2021). It has been shown in many studies that teachers considering students' mathematical thoughts provide a more successful learning environment (Franke \& Kazemi, 2001; Franke et al., 2009). However, studies on how teachers or pre-service teachers provide feedback to students, which strategies, and which questions they use in the problem solving process are limited (Didiş et al., 2016; Toluk-Uçar, 2011). In this sense, it is necessary to investigate how the teacher or pre-service teachers reveal the thoughts of the students and guide them in the problem solving process, where mathematical thoughts are the most intense.

The problem-solving process can be regarded as a complex process which requires thinking at all stages. According to Polya, systematic problem-solving facilitates cognitive learning. Polya (1997) examines these systematic phases in four parts: understanding the problem, making a plan for the solution, implementing the plan, evaluating it. Polya's steps are important in the problem solving process and for the teacher's guidance in this process. In this process, the teacher has the opportunity to observe the students, realize the mistakes and difficulties of the students, and make necessary interventions. It is important to determine where, how, and what kind of mistakes students make, as well as determining whether the answer is correct or incorrect in the problem-solving process since concepts, such as being aware of what the student does, realizing alternative solutions, exploring the relationships between, are more valuable than results in mathematics (Yavuz, 2006). Successful solution of the problem is achieved by developing unique solution strategies by using the connections related to the content instead of applying the solution with a specific algorithm. Therefore, teachers should be more interested in how the student obtained this result rather than the student's result itself, and question how the student solves the problem in the face of correct or incorrect answers (Lim et al., 2020). In such a case, teachers need to approach their students with some questions (Mason, 2020). In understanding and interpreting students' mathematical thoughts, teachers are expected to use questions that will reveal these thoughts (Aziza, 2021; Özdemir \& Altay, 2016). In most studies, it has been observed that teachers or pre-service teachers use questions to reveal and interpret the thoughts of their students (Crespo, 2000; Çelik \& Güzel, 2016; Moyer \& Milewicz, 2002; Tanışl1, 2013). This reveals that questioning is a significant way to reveal students' thoughts. In such a situation, teachers are expected to address some questions to their students.

Some questions, for example, what does the problem want from us? (understanding the problem), what process steps can be followed? (developing a strategy), how do you practice the way you think? (implementing a strategy), is there any other solution? (evaluating) give students a systematic perspective in the problem-solving process. Teachers often make use of some questions in problem-solving process for such reasons as improving students' understanding and making connections between concepts (Ilaria, 2009). In addition, the Turkish Ministry of National Education-MoNE (2013) emphasizes some teacher behaviors such as problem solving, reasoning, association, listening to students' answers and communicating effectively with them. Depending on these behaviors, teachers definitely need to ask questions. The emphasis is not on how teachers will question, but on how to develop a dialogue with students (Moyer \& Milewicz, 2002). Dantonio and Beisenherz (2001) described this process as encouraging students to think critically about their answers, rather than just hearing the teacher's answers. In this context, the questions used in the problem-solving process also emphasize the quality of the teacher's guiding approach. In this process, educators should be capable of guiding with productive, impressive, and thought-provoking questions (Dong et al., 2019; Kabar et al., 2020; Mahmud, 2021; Martino \& Maher, 1999). 
PROBLEMS

OF EDUCATION

IN THE $21^{\text {st }}$ CENTURY

Vol. 80, No. 1,2022

146

It is among the aims of the new education system that teachers guide the student with their questions and enable the student to discover new things (MoNE, 2013). The aim of the guiding approach is to help students reveal their thoughts and learning processes through questions $(\mathrm{Ge}$ \& Land, 2003) and help them reach their solutions (Lin \& Lehman, 1999). Using this approach, teachers can include students to the process more quickly for purposes such as questioning, associating, connecting, identifying, evaluating and remembering misconceptions (Rosenshine et al., 1996). Although pre-service mathematics teachers studying at education faculties in Turkey have some knowledge about the difficulties, misconceptions, and mathematical thinking styles of students as a part of the courses they take (Higher Education Council-YÖK, 2006), their knowledge about guiding students and revealing their thoughts with questions is limited. The literature on problem solving shows that the researchers have frequently focused on students' problem-solving success, problem solving skills, and problem-solving strategies, ignoring the issue of how approaches are used to guide students to the solution. However, in the problem solving process, it may be essential to reveal the students' approaches to the question, and to ask them some questions with an aim to reveal their thoughts. Therefore, even if the student makes mistakes, it is required to question the underlying reasons of these mistakes and to guide the student with appropriate questions, which is an important pedagogical component a teacher should have. Although the studies in the literature emphasized this pedagogical competence, they failed to provide adequate information on the difficulties experienced in the process and the approaches pre-service teachers use. In this sense, the present study is significant in that it tries to deal with the problem solving process in more detail and to offer predictions that will shed light on other studies which investigate the approaches used by pre-service teachers. For this reason, this study aimed to reveal how pre-service teachers guide students in the problemsolving process and which questions they use in this process. For this purpose, solutions were sought for the following research questions:

- How do pre-service primary school mathematics teachers guide students in the problem solving process?

- Which questions do pre-service primary school mathematics teachers use while guiding students in the problem solving process?

\section{Research Methodology}

\section{General Background}

Multiple case - holistic design study was used in this research. In the multiple case study, factors related to two or more situations are used to understand the similarities and differences within and between cases with a holistic approach (Yin, 2014). In this way, in-depth research is carried out on how they affect the situation as well as how they are affected (Yıldırım \& Şimşek, 2013). The cases in this study were five pre-service primary school mathematics teachers. Therefore, it was aimed to present the guiding approaches of pre-service teachers in a realistic and holistic way in the natural environment.

\section{Research Group}

The participants of the study consisted of five $4^{\text {th }}$ grade pre-service primary school mathematics teachers studying at Mathematics education department in a state university. The participants were pre-service teachers under the supervision of the researcher in Teaching Practice course and thus a convenience sampling method was used in the selection of the participants. The participants had taken several theoretical and practical courses such as Problem Solving Strategies, Mathematical Modeling, Special Teaching Methods, Teaching Practice. In these 
courses, the pre-service teachers had the opportunity to learn different teaching techniques as well as having different experiences on how to reveal the students' thoughts. Particularly, some of the applications they made within the scope of Problem Solving Strategies and Mathematical Modeling courses provided them ideas on how to approach problems and how to guide students. For example, the pre-service teachers who learned the problem solving steps of Polya (1997) attempted to use these steps in all problems. In addition, as a part of Special Teaching Methods course, they learned different approaches and different types of questions. Furthermore, in Teaching Practice course, they had the opportunity to test their knowledge and skills in real classroom environment and gained experience in establishing a dialogue with the students and asking them different questions. When they needed to guide the students facing a problem, they adhered to the steps of Polya (1997) and paid attention to ask appropriate questions in a way that would lead the students to the answer at each step. Thus, they had experience in establishing a dialogue with the students and for this reason they were included in the study.

Since the aim of this study was to provide a general framework for the guiding approaches used by pre-service teachers rather than reaching a generalization, it was deemed sufficient to examine a limited number of participants in detail. Because qualitative research is accepted as a research method that aims to examine the researched subject in depth with a small number of people. In relevant quotes in the findings section, pre-service teachers were coded as PT1, PT2, PT3, PT4, and PT5 and students as S1, S2, S3, S4, and so on.

\section{Data Collection}

Dialogues with 7th grade students directed by pre-service teachers in the face of 3 non-routine problems were used in this study. The dialogues firstly video-recorded and then transcribed. Finally, it was tried to reveal the kind of approaches the pre-service teachers used and the questions they used.

The following criteria were taken into consideration in the selection of non-routine questions used by the participants: the questions need to be thought-provoking; they should be solved with different strategies, they should have different solutions, and they should provide the opportunity to create different models. In line with these criteria, several sources were reviewed, the appropriate problems were listed, and the most suitable 3 questions were selected for the study. The selected problems are as follows:

1. A tourist group of 228 people wants to look at the city at the top of a high building. There is only one elevator in the building with a capacity of 24 people. How many tours must the elevator take to get the whole group to the top of the building?

2. Aunt Ayşe decides to go to the market for holiday shopping. However, she needs to do her shopping in a short time. Aunt Ayşe sees that there is a queue at the cash register. There can be a minimum of 3 and a maximum of 7 items in the cash register. Considering that the barcodes are read in 3 seconds and all products are packaged in 20 seconds at a time, develop and express your own mathematical model, and answer the questions below in accordance with the model you developed.

a) Considering that Aunt Ayşe is in the 6th place, what is the minimum time it takes for Aunt Ayşe to take the turn?

b) Considering that Aunt Ayșe is in the 6th place, what is the maximum time it takes for Aunt Ayşe to take the turn?

3. You are thinking of making a long call on your phone. According to the tariff of the line you use, the first minute of the call is charged 100 cent, and 20 cents for each minute in the ongoing call. For this phone call, develop a mathematical model to express your debt for any $t$ call duration.

The participants performed practicum with groups of 3-4 students. First of all, a participant raised a problem to the whole group and started a discussion with a student. The 
Fatma CUMHUR. Pre-service teachers' approaches to guiding students in problem solving process

PROBLEMS

OF EDUCATION

IN THE $21^{\text {st }}$ CENTURY Vol. 80, No. 1,2022

148

other students observed the discussion between the teacher and the student and expressed their opinions when questions were posed to them. In this way, each problem solving process was carried out in about 20-30 minutes in different turns.

\section{Data Analysis}

In the study, it was aimed to reveal how the pre-service teachers approached the students in the problem-solving process, and thus the approaches they adopted in this process were examined in detail. The content analysis method was used for data analysis since the pre-service teachers' approaches in problem solving process were examined. The aim of content analysis is to reveal the concepts and relationships that help to explain the obtained data (Çepni, 2012). In educational research, diaries, written texts and interview transcripts are generally examined using content analysis (Patton, 2002). In the study, category analysis of content analysis techniques was used (Y 1ldırım \& Şimşek, 2013). At this stage, the researcher created a codecategory-theme system. In this sense, the researcher analyzed the information he obtained and tried to divide it into meaningful parts and to understand what each part means conceptually. These sections, which form a meaningful whole in themselves, were named by the researcher. In this context, the transcripts of the interviews of each participant were examined carefully and the guiding approaches they adopted were tried to be determined. The questions that the participants asked the students during the problem-solving process revealed the general structure of the guiding approach. In this way, the questions used by the participants were grouped and each group was examined under a different theme. An excerpt of a participant's dialogue with the student is taken and how the content analysis was carried out is represented below.

PT2: Well, let me give you an example in this question. You, 12 people, go to dinner in a restaurant and the elevator in the restaurant can only carry 5 people, how can you solve this question.

$\mathrm{S} 2$ : Teacher, 12 is divided by 5 and remains 2 . Again it is a decimal number.

PT2: Let's think about it, friends, for example, the two of you remaining, the two of you, you are the only ones down, how would you go up.

S2: (Two students pointed out): We would go up with a separate elevator

PT2: Right, so how many tours would it be?

S2: There would be 3 tours in total

PT2: Well done children, let's try to apply the solution steps for our own question, just as we have solved this problem.

$\mathrm{S} 2$ : Teacher, then the answer to our question is 10 because the remaining 12 people make separate tours.

In order to reveal the approach of the participant in the dialogue, first of all, his/her purpose was examined. Throughout the dialogue, the participants' answers to the student helped to reveal his/her purpose. For this reason, it was understood that the approaches used by the participants to student answers were related to "How?" rather than "What?". This required that all statements used by the candidate throughout the dialogue must be analyzed. Since content analysis requires more analysis than observation, all statements were carefully read and analyzed in the study. As a result of the analysis, the fact that the participants generally used questions to provide answers and guided the students with questions required the need to group these questions. In this sense, various themes were created in line with the purposes of the questions used throughout the dialogue and a general structure was revealed as a result of these themes. 


\section{Research Results}

\section{Preservice Teachers'Approaches to Guiding}

The findings showed that participants generally followed Polya's (1997) steps in problem solving process and directed the students in accordance with these steps. While performing these steps, participants generally preferred to ask questions during the problem-solving process in order to reveal the students' thoughts and overcome the difficulties they faced. The question types they used showed that participants mostly used the questions to guide students to the solution and to probe their answers. The participants' use of Polya (1997)'s steps and questions to perform these steps enabled the use of different question types. The participants also used these questions in a particular order in accordance with the steps of Polya (1997): questions that require an understanding of the problem (Do you understand the question?), questions that require determining a strategy (What is your idea for a solution?), questions that require implementing a strategy (How do you solve it?), and questions that require evaluation of the solution (Do you understand the solution?). Following this sequence, the participants asked the students questions such as guiding, searching, identifying misconceptions, connecting, role playing and re-focusing. The following figure shows the approaches and question types the participants used in general:

\section{Figure 1}

The Participants' Approaches to Guiding in Problem-Solving Process

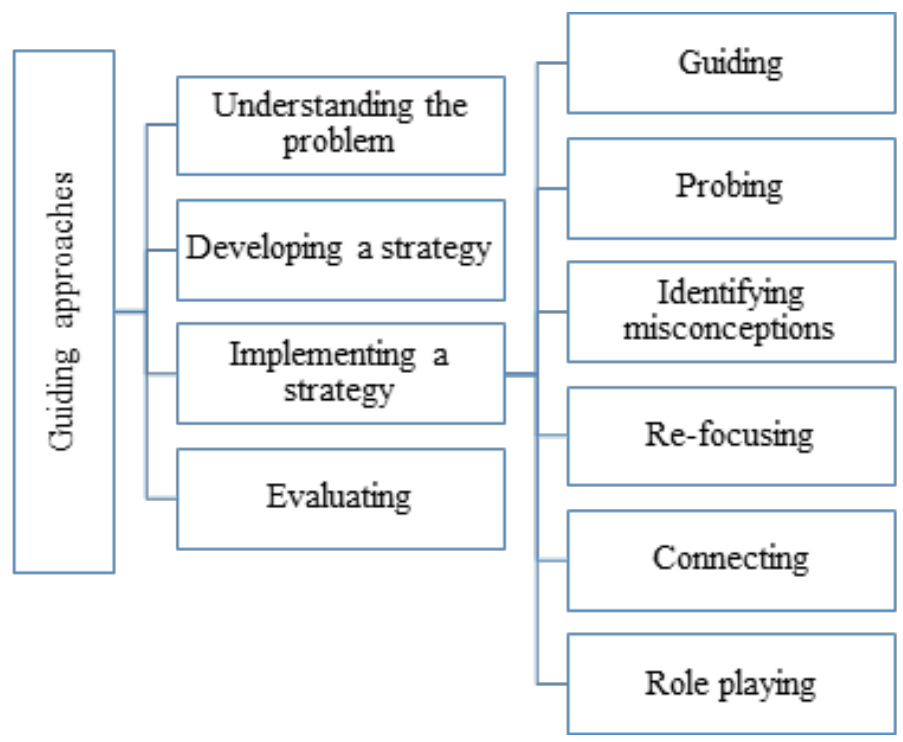

Figure 1 illustrates a general outline of the approaches and question types the participants used in their problem solving process. Some excerpts of the dialogues of the participants with the students under these headings are presented as follows:

\section{Understanding the Problem}

The participants generally adopted approaches to reveal whether the students understood the problem after they asked the problem. Some participants tried to understand whether the students understood the problem with closed-ended questions whereas others used open-ended questions. For example: 
PROBLEMS

OF EDUCATION

IN THE $21^{\text {st }}$ CENTURY

Vol. 80 , No. 1,2022

150

PT1: Do you understand the question?

S1: Yes

PT1: How do we solve the question?

The dialogue showed that the pre-service teacher asked the problem to the students and then tried to find out whether the problem was understood with 'yes' or 'no' question. Similarly,

PT2: Do you understand the question?

S2: Yes.

PT2: Well! If you solve it, I will follow your solution.

In this dialogue, PT2 led the student directly to the solution process without revealing the understood parts of the problem. A different participant asked the problem to the group and initiated the solution part directly with the question 'Does anyone want to solve this question?' without checking whether the students understood the problem. The participant focused directly on problem-solving rather than guiding his/her students to problem-solving and developing appropriate solution strategies. In contrast, another participant checked whether the student understood the problem in detail as follows:

PT3: Did you read and understand the question?

S3: Yes, teacher

PT3: Can you explain?

S3: (explains $3^{\text {rd }}$ problem) 100 cent in the first minute, 20 cents in the next minutes, but what does " $t$ " mean?

PT3: If " $\mathrm{t}$ " means one minute-talk or 10 minutes-talk, we use a letter such as $\mathrm{x}, \mathrm{y}, \mathrm{z}$ since it is variable.

As seen in the dialogue, the student stated that he/she understood the problem at first but when the pre-service teacher requests for an explanation it was revealed that he/she did not fully understand the problem. This shows that such questions as "Did you understand the question? "are not adequate to understand students' thought and thus detailed questions such as "What do you understand from the question?" should be asked.

PT4: How would you explain the question clearly if you wanted to tell me?

S4: (explains $1^{\text {st }}$ problem) Teacher, in this question, there is a tourist group of 228 people, people in this group want to go upstairs, but there is a lift for 24 people in the building, and this question asks how many tours we will take these people up!

PT4: Well done! You explained the question in a very nice way.

In this dialogue, the participants aimed to reveal the clarity of the problem with an openended question and encouraged the student to explain the problem in detail.

S5: Teacher, I did not understand this question.

PT5: Okay, now let's read it together to understand the question. Now, be the person in this question, okay? ( $3^{\text {rd }}$ problem).

S5: Yes, teacher.

PT5: Now, you are going to have a long call on the phone, and the first minute of this phone's tariff is 100 cents. If you talk on the phone for a longer time and this time is not known, except for the first minute you will pay 20 cents for every other minute. Now, do you understand this question?

S5: Yes, teacher, I understood the question, but why time of the call is not clear, then how can we solve it? 
PROBLEMS

OF EDUCATION

IN THE $21^{\text {st }}$ CENTURY

Vol. 80 , No. 1,2022

As seen in the dialogue, the participant explained the problem with more descriptive words. It is noteworthy that the participant considered the student as the protagonist of the problem and connected the problem with the student's daily life. However, the fact that the student expressed that he/she did not understand the problem sufficiently showed that the participant's explanatory attitude was not sufficient.

\section{Developing a Strategy}

During the strategy development phase, students are expected to make a connection between what is given and what is required, to predict which process steps can be followed, and to make preliminary trials for a solution. In this process, the participants generally asked the students the question "how can we solve them?" and aimed to present the students' solutions. However, it was seen in some dialogues that the solution strategies were not sufficiently revealed. For example,

PT1: How do we solve the question?

S6: We will divide 228 people into 24 and find out how many tours the elevator will go.

PT1: What is the result?

S6: 9

In this dialogue, the participants focused on finding the result immediately after presenting the student's solution strategy. In a different dialogue,

PT2: Do you understand the question?

S7: Yes.

PT2: So you solve it, I will follow.

After the student's statement that he/she understood the problem, the teacher led the student directly to the solution and did not reveal the student's ideas about the problem. In addition, it was seen that another participant did not take into account the steps of understanding the problem and developing a strategy and led the students to a solution with the question" who wants to solve this question?" A different participant adopted the following approach in developing strategy.

PT1: If you wanted to solve this question, how would you go on, what procedures would you use? S6: Teacher, I would use division in this question.

PT1: So, why would you use the division?

S6: Because, teacher, we have to take people up and down. So, I believe we could find the number of tours this way.

It is seen that the participant aimed to present the student's solution strategy with a more questioning approach. In general, participants tried to reveal students' thoughts in the context of strategy development, but they used less questions that would require extensive and detailed information. It was noted that participants did not show any approach in order to establish a connection between what was given and what was required in this process or to discuss students' solution strategies.

\section{Implementing a Strategy}

The participants observed students during the implementation of the strategy and posed questions in the process. It is understood that pre-service teachers tried to achieve goals 
PROBLEMS

OF EDUCATION

IN THE $21^{\text {st }}$ CENTURY

Vol. 80, No. 1,2022

152

such as directing, researching, connecting and refocusing students with these questions. The participants often asked students to re-focus when the students made mistakes. In addition, they asked questions to identify misconceptions, connect, and demonstrate purposes to guide students in situations where they had difficulties.

\section{Guiding}

The guiding approach plays a facilitating role in reaching the solution if the students are unable to answer or provide incorrect or incomplete answers. In this case, the participants tried to simplify the process by dividing the question to simple steps and giving clues to the students.

PT4: Can you find a formula for this?

S8: I don't know how to find it.

PT4: Well, let me explain to you, let's find it together. Let's say $\mathrm{x}$ is our product number, so in how many seconds are each product read.

S8: 3

PT4: So how many seconds is the total product read?

S8: 3.x

PT4: How much time is it for packaging?

S8: 20

PT4: How many people do you expect if you are the $6^{\text {th }}$ person?

S8: 5

PT4: Why?

S8: Because we get ourselves out 6-1 $=5$

PT4: Well, if there are that many $\mathrm{k}$ and we are the third, then we subtract ourselves from $\mathrm{k}$, right? PT4: So let's write the formula

S8: $(x \cdot 3+20)$. Number of persons $=(x \cdot 3+20)(k-1)$.

The examination of the dialogue showed that the student did not know how to approach the solution. More importantly, the participant preferred to ask questions in a way that led the student to a step-by-step solution. These questions revealed that the participant did not guide student to improve his/her problem-solving and algebraic reasoning skills. Instead, it was seen that the participant directly led the student to a solution through hint questions that made it easier to obtain answers.

\section{Probing}

The probing approach allows students to deepen their ideas on the subject and to think more comprehensively about their answers. With these questions which include high-level thinking skills, students are expected to develop reasoning, analyzing, interpreting, and critical thinking skills.

PT3: First solve by taking the value 10, and then write the variable.

S9: $10-1=9,9.20=180,180+100=280$

PT3: Why did you subtract 1 ?

S9: Because the first minute is already clear.

PT3: If $\mathrm{t}$ were then 10 , it would still be a subtraction. Then write algebraically, subtracting 1 minute from the time $\mathrm{t}$

S9: $\mathrm{t}-1$

PT3: Then why multiply 9 and 20?

S9: Because it was 20 seconds for the rest. 
It was seen in the dialogue that the participant used questions that require inquiring the answer of the student in the solution process. This reveals that the participant used questions to examine the inter-quantitative relationships in the problem.

S10: Teacher, we tried to solve this question, but we didn't come up with a full answer. We found 9.5 .

PT4: How did you reach this answer?

S10: In this question, we divided the number 228 to 24 and the result was 9.5 . So the elevator should make 9.5 tours.

PT4: Why did you divide?

S10: Teacher, since we have grouped people here, and the division process is used when grouping.

The dialogue showed that the student's inability to find the result as an integer caused confusion in the student. The participant exhibited a probing approach with questions such as "how did you reach that result?" and "Why did you do the division?". This helped the students to deepen their answers.

\section{Identifying Misconceptions}

Most students have misconceptions. In order to eliminate misconceptions during the course, questions are often used. Therefore, predicting the parts students will face a challenge and asking questions to overcome the difficulty is an important task for teachers.

PT1: So what should you do with t-1?

S11: t-1.20

PT1: Is t-1.20 equal to (t-1) .20?

S11: Yes

PT1: Can you multiply two expressions, let's see is it equal?

S11: $\mathrm{t}-20,20 \mathrm{t}-20$

PT1: Is it equal?

S11: No, but which one is right, teacher?

PT1: We subtracted 1 from 10 and multiplied the whole by 20, so what?

S11: I have to multiply the whole, so (t-1) .20

The answer in the dialogue revealed that the student had a misconception. On the other hand, the participant helped the students realize his/her mistake instead of providing an immediate feedback. It is seen that the participants aimed to eliminate the misconceptions of the student and achieve his/her aim with the questions.

\section{Re-focusing}

The refocus approach aims to refocus students on key points in the problem when they move away from the correct way. This approach was frequently used by the participants.

PT2: You understood the question well, but you thought incorrectly in somewhere. So, does anybody want to explain this?

S12: But teacher, the division is the correct way for this question, we have solved a similar problem to this question without being left.

The fact that the participant stated that the solution was incorrect showed that he/she refocused the students on the question. However, the fact that he/she used a general expression stating that "you thought incorrectly in somewhere " and did not mention specific points were not sufficient for students to understand exactly what the focus would be. A similar situation was observed in another participant's dialogue: 
Fatma CUMHUR. Pre-service teachers' approaches to guiding students in problem solving process

PROBLEMS

OF EDUCATION

IN THE $21^{\text {st }}$ CENTURY

Vol. 80, No. 1,2022

154

PT1: Friends, it is correct to divide in this question, but you make a mistake in somewhere. Does anybody want to explain what the mistake is?

S13: No teacher, we did not understand the mistake.

In a different dialogue, it was seen that the participant tried to make up for the student's insufficiency as follows:

PT5: Well done, you are very close to solving the problem, but your answer is missing, do you want to find?

S5: But teacher it is the right solution.

PT5: Well, Is the first spoken minute certain?

S5: Yes, teacher, it is certain and 100 cents.

PT5: Yeah. In this algebraic expression, we show the first minute as (t-1), right? Because the first spoken minute was 100 cents, or we subtracted it.

S5: Yes, teacher.

PT5: So how can we use an algebraic expression or equation in this question?

S5: Teacher, then $100+(\mathrm{t}-1) .20$

It is understood that the participants aimed to conclude the student's incomplete answer in this dialogue. Seeing that the student's solution had not yet reached a conclusion, the participant guided the student to focus on the question again. However, it is noteworthy that the statements of the participant were in a way that would enable the student to close this gap himself/herself rather than allowing the student to see the lack of solution. Here, instead of focusing on the points where the student made mistakes, the participant preferred explanatory questions instead of focusing on the points where the student made mistakes.

\section{Connecting}

The connecting approach aims to connect different aspects of a situation or to link it to real life. In this approach, it is aimed to compare two or more situations and to reveal similarities or differences. In the study, the participants frequently used connecting strategies and mostly aimed to establish connections with daily life.

PT2: Well, let me give you an example in this question. You, 12 people, go to dinner in a restaurant and the elevator in the restaurant can only carry 5 people, how can you solve this question.

$\mathrm{S} 2$ : Teacher, 12 is divided by 5 and remains 2 . Again it is a decimal number.

PT2: Let's think about it, friends, for example, the two of you remaining, the two of you, you are the only ones down, how would you go up.

S2: (Two students pointed out): We would go up with a separate elevator

PT2: Right, so how many tours would it be?

S2: There would be 3 tours in total

PT2: Well done children, let's try to apply the solution steps for our own question, just as we have solved this problem.

$\mathrm{S} 2$ : Teacher, then the answer to our question is 10 because the remaining 12 people make separate tours.

When the students could not find the answer, the participants tried to provide a simple example and tried to establish a connection between the problem and daily life by engaging the students in the event. The participants' simplification and connection strategies contributed to the students' problem-solving.

S4: I did the operation and found 3.2, so it should be a 3.2 .

PT4: Well, how do we make 3.2 tours? 
S4: Teacher, but the result should be 3.2 .

PT4: Would not we do a full tour, going upstairs with our family

S4: Yes, teacher.

PT4: So, in other words, are we able to go up to the top floor as a decimal number?

S4: No, teacher, I got it, what my friends say is, they are going to go up in a separate time because the elevator can only make a full tour. It cannot make a decimal tour.

PT4: Well done, you thought right.

Similarly, in this dialogue, it is seen that the student had difficulty in understanding and the participant tried to overcome this difficulty by connecting the situation with daily life.

S12: Yes, teacher, I understand the question, but why is it not clear how long we talk, then how can we solve this question?

PT2: You know, we learned algebraic expressions before.

S12: Yes, teacher, we did.

PT2: Let's remember algebraic expressions with a few examples before moving to the question.

S12: Okay, teacher.

PT2: What is 2 more of a number?

S12: If we call the number " $a$ ", it would be a +2 , teacher

PT2: Good. Now there is an unknown expression in this question, or how do you write this algebraic expression in the question.

S12: Then we'll find out it $100+20$ th.

In this dialogue, the participant made a connection with the student's prior knowledge and established a bridge between the information given in the problem and this information.

\section{Role playing}

The role playing approach aims to act out the incomprehensible problem in accordance with the environment. This approach, which is considered as gamification, has enabled students to understand the problem better. Not every problem is suitable for role playing, which makes this approach less common than others.

PT3: Friends, let's solve this question practically. Now, in turn, let's get out of here as seven people.

S13: Teacher, my friend and I stayed here, what will we do.

PT3: What do you think your friends should do in this step?

S13: Teacher, they can also come in a separate tour. So, the answer will be 4 tours.

In this dialogue, the participant responded to the students who persistently misrepresent the result, and used role playing approach by acting out a similar situation. The participant took different values appropriate to the role play instead of the values in the problem, enabled the students to understand the problem better. The participant also used approaches to reveal the students' solution strategies during the acting out of the problem. In response to the student's incorrect answers, he/she made the student realize his/her mistake by asking questions that would establish connections with daily life. It was seen that the students establishing a connection between the values in the problem through role playing got the correct result.

\section{Evaluating}

The evaluation approach aims to determine whether the problem is understood, what results will be achieved when different values are given, or to seek different solutions. This 
Fatma CUMHUR. Pre-service teachers' approaches to guiding students in problem solving process

PROBLEMS

OF EDUCATION

IN THE $21^{\text {st }}$ CENTURY Vol. 80 , No. 1,202

156

approach was often ignored by the participants. Instead, they thought that it would be sufficient to find the result and they did not exhibit any further approaches. At this stage, the participants checked whether or not the problem was understood with simple questions such as "Did you understand?". They did not ask questions that revealed how they would form the problem in different situations.

PT4: Can you tell me the solution to the problem again?

S14: Teacher, it is now 100 cents in the first minute, this fee is certain, the other minutes $t-1$, the first minute we took this algebraic expression. We will write 100 , and then we will multiply $\mathrm{t}-1$ by 20 for the other minutes. The debt will be $100+20$. (t-1).

PT4: Well done, you understood very well what I told you. Your solution is correct.

S14: Yes.

In this dialogue, it is seen that the student explained the solution to the problem with their own statements and the pre-service teacher tried to clarify the unclear points.

PT1: Well, is there anyone who did not understand the logic of this question?

S1: No, teacher.

In this dialogue, the participant regularly revealed the comprehensibility of the solution and did not provide further details.

\section{Discussion}

It was found in the present study that learning new and contemporary approaches during their undergraduate education helped the participants integrate the knowledge they learned into practice. Their questions about understanding the problem and developing a strategy in students' problem-solving process showed that the process of understanding the problem and making a plan for the solution was taken into account before the solution process. Most studies have highlighted the importance of cognitive steps such as understanding the problem as the first step in the problem-solving process, establishing a relationship between what is given and what is required, and choosing strategies that can be used for solution (Memnun, 2014; Turnuklu \& Yesildere, 2005). In addition, it was stated in the literature that inadequate definition of the problem will pave the way to difficulties for students in the problem solving process (Gökkurt \& Soylu, 2013; Karataş \& Güven, 2004). It was revealed that the part that was not understood cannot be expressed with some questions such as 'Do you understand the problem' and 'How do you solve it' used in these steps. The students provided surface level answers to these questions. However, questions such as 'what did you understand from the problem' and 'why did you choose this strategy' allowed the students to focus on the problem and the solution and to provide more detail. Thus, the students initiated a better solution process by clarifying the points that were not understood at the beginning of the process. It was stated in most studies that the questions used in the process affected students' thinking and pushed them into a better solution process (Doerr, 2006; Graham et al., 2021; Yenmez et al., 2017).

During guiding, the participants used questions that serve the purpose of guiding, questioning, identifying misconceptions, re-focusing, connecting, and role playing. Although it was found that questions such as connecting and re-focusing were used more frequently, the structure of the problem was decisive in the type and amount of the question to be used. The question types showed that they successfully helped the participants to lead students to reach the solution to the problem. However, it should be noted that only some of the questions facilitated more student thinking because pre-service teachers may have difficulty in controlling the progress of the conversation in the process. In such cases, they may prefer to use more 
explanatory questions rather than being thought-provoking. On the other hand, explanatory questions can prevent the student from thinking when the answer is considered confidential. Nevertheless, effective questions facilitate students' high-level thinking (Dong et al., 2019; Schjem, 2021; Yenmez et al., 2017).

Pre-service teachers believe that it is necessary to show their students the ability to handle a problem in various ways while solving a problem (Kayan \& Cakıroglu, 2008). In the present study, the participants enabled students to realize their mistakes by intervening in the questions when the students made a mistake, Garcia et al. (2010) stated that the prompts to be used when students have difficulties in the solution process are the responsibility of the teacher. In particular, making connections with daily life and role playing were effective in concretizing the situation. Similar results were found in some studies such as Yenmez et al. (2017) and Galbraith and Stillman (2006). However, some questions, such as 'you're in the wrong place?', which were asked to refocus students on the problem when they were distracted from the answer, failed to focus students on the key point. In such a case, the pre-service teacher's emphasis on the wrong part and focusing on the dimensions of the error may provide more effective answers.

Answering the problem easily cannot be accepted as proof of good problem solving skills (Yavuz, 2006). Problem-solving is not only an ability to achieve results but a process that requires thinking at all stages. It requires thinking at all stages of the process (Kukey, Aslaner \& Tutak, 2019). This can be regarded as a good indication that problem-solving is not only an ability to achieve results. Some questions such as 'is it understood?' were at the surface level and did not force students to elaborate on what they understand in detail. Polya (1997) discussed the evaluation step in the problem solving process in detail and offered students a more inquisitive approach in finding different ways and retrying the solution with different values. It is emphasized in some studies that different solutions should be included and these solutions should be discussed in the classroom (Cai \& Kenney, 2000; Kayan \& Cakiroglu, 2008). Although pre-service teachers believe that problem-solving is process-oriented, their practices are result-oriented (Biber et al., 2017). Pre-service teachers may think that the solution is sufficient when students answer the problem and they may not need different questions to develop additional strategies. The fact that the participants wanted to complete the problemsolving process in a short time and regarded only one answer sufficient led them to provide insufficient guidance in the evaluation phase. Similarly, in some studies, it has been observed that pre-service teachers have a result-oriented approach in the problem-solving process (e.g. Biber et al., 2017).

\section{Conclusions and Suggestions}

The findings of this study showed that the participants followed the following problem solving steps of Polya (1997) in the guiding approaches in problem solving process: understanding the problem, developing a strategy, implementation of a strategy, and evaluating. In the problem-solving process, the participants generally followed the students' solutions and were able to respond to the difficulties faced by the students during the solution. During the implementation of the strategy, they preferred some approaches such as identifying misconceptions, connection, re-focusing, and role playing, when students had difficulty in understanding. In addition, the participants focused on finding the result in the problem-solving process, but they did not put much effort to evaluate the result. On the basis of the finding of the present study, it is recommended to enhance the practicum opportunities that will enable the development of guidance approaches of pre-service teachers and to promote such studies. Problem solving should not be regarded only as a part of the mathematics course, instead it should be considered as a facilitating factor that can be used at every stage of human life. In this regard, it is important to examine and develop the pedagogical approaches teachers or preservice teachers use in order to improve students' problem-solving skills. 
PROBLEMS

OF EDUCATION IN THE $21^{\text {st }}$ CENTURY Vol. 80, No. 1,2022

158

The present study is not without its limitations. First, the study was carried out with five participants. Second, student levels were ignored. Third, only three questions were used to examine the participants' approaches. These limitations indicate that different results can be obtained when the study is conducted under different conditions. In this sense, studies can be conducted to see what kind of results can be obtained by observing student levels and using different problems in different studies. In this sense, student levels should be considered in future studies and different problems should be used. In addition, increasing the number of the participants or including in-service teachers may lead to different results.

\section{References}

Aziza, M. (2021). A teacher questioning activity: the use of oral open-ended questions in mathematics classroom. Qualitative Research in Education, 10(1), 31-61. https://doi.org/10.17583/qre.2021.6475

Baki, A. (2006). Kuramdan uygulamaya matematik eğitimi [Mathematics education from theory to practice]. Derya Bookstore.

Biber, B. T., Aylar, E., Ay, Z. S., \& İspir, O. A. (2017). İlköğretim matematik öğretmen adaylarının problem çözmeye dair pedagojik alan bilgilerinin sınıf içi gözlem ve görüşme yoluyla belirlenmesi [Pre-service primary school mathematics teachers' pedagogical content knowledge of problem solving through interviews and in-class practice observations]. Kastamonu Education Journal, 25(4), 1483-1498. https://dergipark.org.tr/tr/pub/kefdergi/issue/30766/332494

Cai, J., \& Kenney, P. A. (2000). Fostering mathematical thinking through multiple solutions. Mathematics Teaching in the Middle School, 5(8), 534-539. https://doi.org/10.5951/MTMS.5.8.0534

Carpenter, T. P., Fennema, E., Peterson, P. L., Chiang, C. P., \& Loef, M. (1989). Using knowledge of children's mathematics thinking in classroom teaching: An experimental study. American Educational Research Journal, 26(4), 499-531. https://doi.org/10.3102/00028312026004499

Crespo, S. (2000). Seeing more than right and wrong answers: Pre-service teachers' interpretations of students' mathematical work. Journal of Mathematics Teacher Education, 3(2), 155-181. https://doi.org/10.1023/A:1009999016764

Çelik, Ö. A., \& Güzel, B. E. (2016). Bir matematil öğretmeninin ders imecesi boyunca öğrencilerin düşüncelerini ortaya çıkaracak soru sorma yaklaşımları [A mathematics teacher's questioning approaches for revealing students' thinking during lesson study]. Turkish Journal of Computer and Mathematics Education, 7(2), 365-392. https://doi.org/10.16949/turcomat.67541

Çepni, S. (2012). Araştırma ve proje çalışmalarına giriş [Introduction to research and project work]. Celepler Printing.

Dantonio, M., \& Beisenherz, P. C. (2001). Learning to question, questioning to learn: Developing effective teacher questioning practices. Allyn \& Bacon.

Didiş, M. G., Erbaş, A. K., \& Çetinkaya, B. (2016). Matematik öğretmen adaylarının öğrenci hatalarına yönelik pedagojik yaklaşımlarının matematiksel modelleme bağlamında incelenmesi [Investigating prospective mathematics teachers' pedagogical approaches in response to students' errors in the context of mathematical modeling activities]. Elementary Education Online, 15(4), 1367-1384. https://doi.org/10.17051/io.2016.75429

Didiş, M. G., Erbaş, A. K., Çetinkaya, B., Çakıroğlu, E., \& Alacacı, C. (2016). Exploring preservice secondary mathematics teachers' interpretation of student thinking through analysing students' work in modelling. Mathematics Education Research Journal, 28(3), 349-378. https://doi.org/10.1007/s13394-016-0170-6

Doerr, H. M. (2006). Examining the tasks of teaching when using students' mathematical thinking. Educational Studies in Mathematics, 62, 3-24. https://doi.org/10.1007/s10649-006-4437-9

Dong, L., Clarke, D., Cao, Y., Wang, L., \& Seah, W. T. (2019). Teacher questioning practices over a sequence of consecutive lessons: A case study of two mathematics teachers. Sustainability, 11(1), 139. https://doi.org/10.3390/su11010139

Even, R., \& Markovits, Z. (1995). Some aspects of teachers' and students' views on student reasoning and knowledge construction. International Journal of Mathematical Education in Science and Technology, 26(4), 531-544. https://doi.org/10.1080/0020739950260407 
Franke M.L., \& Kazemi E. (2001). Learning to teach mathematics: Focus on student thinking. Theory into Practice, 40(2), 102-109. https://doi.org/10.1207/s15430421tip4002_4

Franke, M. L., Webb, N. M., Chan, A. G., Ing, M., Freund, D., \& Battey, D. (2009). Teacher questioning to elicit students' mathematical thinking in elementary school classrooms. Journal of Teacher Education, 60(4), 380-392. https://doi.org/10.1177/0022487109339906

Galbraith, P. L., \& G. Stillman. (2006). A framework for identifying student blockages during transitions in the modelling process. ZDM - Mathematics Education, 38(2), 143-162. https://doi.org/10.1007/BF02655886

García, F. J., K. Maass, \& G. Wake. (2010). Theory meets practice: working pragmatically within different cultures and traditions. R. Lesh, P. L. Galbraith, C. R. Haines, \& A. Hurford (Eds.), Modeling Students' Mathematical Modeling Competencies (pp. 445-457). Springer. https://doi.org/10.1007/978-1-4419-0561-1_38

Ge, X., \& Land, S. M. (2003). Scaffolding students' problem-solving processes in an ill-structured task using question prompts and peer interactions. Educational Technology Research and Development, 51(1), 21-38. https://doi.org/10.1007/BF02504515

Gokkurt, B., \& Soylu, Y. (2013). Öğrencilerin problem çözme sürecinde anlam bilgisini kullanma düzeyleri [Levels of students' use of semantic knowledge in problem solving process]. Kastamonu Education Journal, 21(2), 469-488. https://app.trdizin.gov.tr/makale/TVRRM09ESTNOdz09/ ogrencilerin-problem-cozme-surecinde-anlam-bilgisini-kullanma-duzeyleri-

Graham, M. A., van Staden, S., \& Dzamesi, P. D. (2021). Communicating lesson objectives and effective questioning in the mathematics classroom: The ghanaian junior high school experience. International Journal of Instruction, 14(4), 965-984. https://doi.org/10.29333/iji.2021.14455a

Ilaria, D. R. (2009). Teacher questions that engage students in mathematical conversation. [Unpublished doctoral dissertation]. Rutgers University.

Jonassen, D. H. (2000). Toward a design theory of problem solving. Educational Technology: Research and Development, 48(4), 63-85. https://doi.org/10.1007/BF02300500

Kabar, M. G. D., \& Tasdan, B. T. (2020). Examining the change of pre-service middle school mathematics teachers' questioning approaches through clinical interviews. Mathematics Teacher Education and Development, 22(1), 115-138. (EJ1272255). https://eric.ed.gov/?id=EJ1272255

Karatas, I., \& Guven, B. (2004). Determining the problem solving skills of 8th grade students: A case study. Journal of National Education, 163. http://dhgm.meb.gov.tr/yayimlar/dergiler/Milli Egitim_Dergisi/163/karatas.htm

Kayan, F., \& Cakiroglu, E. (2008). İlköğretim matematik öğretmen adaylarının matematiksel problem çözmeye yönelik inançları [Preservice elementary mathematics teachers' mathematical problem solving beliefs]. Hacettepe University Journal of Education, 35(35), 218-226. https://dergipark. org.tr/tr/pub/hunefd/issue/7803/102288

Kukey, E., Aslaner, R., \& Tutak, T. (2019). An investigation of the problem solving strategies used of middle school students for of the assumption component of mathematical thinking. Journal of Computer and Education Research, 7(13), 146-170. https://doi.org/10.18009/jcer.535610

Lim, W., Lee, J. E., Tyson, K., Kim, H. J., \& Kim, J. (2020). An integral part of facilitating mathematical discussions: Follow-up questioning. International Journal of Science and Mathematics Education, 18(2), 377-398. https://doi.org/10.1007/s10763-019-09966-3

Lin, X., \& Lehman, J. D. (1999). Supporting learning of variable control in a computer-based biology environment: Effects of prompting college students to reflect on their own thinking. Journal of Research in Science Teaching: The Official Journal of the National Association for Research in Science Teaching, 36(7), 837858. https://doi.org/10.1002/(SICI)1098-2736(199909)36:7<837::AID-TEA6>3.0.CO;2-U

Mahmud, M. S. (2021). Implementation of oral questioning in assessing student learning in mathematics teaching in primary schools. Turkish Journal of Computer and Mathematics Education (TURCOMAT), 12(5), 137-143. https://doi.org/10.17762/turcomat.v12i5.805

Martino, A. M., \& Maher, C. A. (1999). Teacher questioning to promote justification and generalization in mathematics: What research practice has taught us. Journal of Mathematical Behavior, 18(1), 53-78. https://doi.org/10.1016/S0732-3123(99)00017-6

Mason, J. (2020). Effective questioning and responding in the mathematics classroom 1. G. Ineson \& H. Povey (Eds.), Debates in mathematics education (2nd ed., pp. 131-142). Routledge. https://doi.org/10.4324/9780429021015 
Fatma CUMHUR. Pre-service teachers' approaches to guiding students in problem solving process

PROBLEMS

OF EDUCATION IN THE $21^{\text {st }}$ CENTURY Vol. 80 , No. 1,2022

160

Memnun, D. S. (2014). Beşinci ve altıncı sınıf öğrencilerinin sözel problemleri çözme konusundaki yetersizlikleri ve problem çözümlerindeki hataları [Fifth and sixth grade students' deficiencies on word problem solving and failures in the problem solving process]. Turkish Journal of Computer and Mathematics Education, 5(2), 158-175. https://dergipark.org.tr/tr/pub/turkbilmat/ issue $/ 21573 / 231491$

Ministry of National Education [MoNE]. (2013). Secondary school mathematics curriculum (grades 5, 6, 7 and 8). Ankara.

Moyer, P. S., \& Milewicz, E. (2002). Learning to question: Categories of questioning used by preservice teachers during diagnostic mathematics interviews. Journal of Mathematics Teacher Education, 5(4), 293-315. https://doi.org/10.1023/A:1021251912775

National Council of Teachers of Mathematics [NCTM] (2000). Principles and standards for school mathematics. https://www.nctm.org/uploadedFiles/Standards_and_Positions/PSSM ExecutiveSummary.pdf

Özdemir, İ. E. Y., \& Altay, M. K. (2016). Sınıf Öğretmeni Adaylarının Öğrencilerin Matematiksel Düşüncelerini Ortaya Çıkarma ve Yorumlama Becerileri [Pre-service primary teachers' skills in revealing and interpreting students' mathematical thinking]. Elementary Education Online, 15(1), 23-39. https://doi.org/10.17051/io.2016.92637

Patton, M. Q. (2002). Qualitative research and evaluation methods (3rd ed.). Sage Publications.

Peterson, P. L. (1988). Teachers' and students' cognitional knowledge for classroom teaching and learning. Educational researcher, 17(5), 5-14. https://doi.org/10.3102/0013189X017005005

Polya, G. (1997). How to solve it? (Trans: F. Halatci). Sistem Publishing.

Roberts, S. A. (2021). Learning and unlearning through questioning practices: Middle grades mathematics teachers' transformations to support english learners. Mathematics Teacher Education and Development, 23(1), 135-155. https://orcid.org/0000-0002-7191-9175

Rosenshine, B., Meister, C., \& Chapman, S. (1996). Teaching students to generate questions: A review of the intervention studies. Review of educational research, 66(2), 181-221. https://doi.org/10.3102/00346543066002181

Schjem, T. (2021). Questioning questioning: The" why" and" how" of mathematics [Unpublished master's dissertation]. Norwegian University of Science and Technology.

Schoenfeld, A. H. (1989). Explorations of students' mathematical beliefs and behavior. Journal for Research in Mathematics Education, 20(4), 338-355. https://doi.org/10.2307/749440

Swing, S. R., Stoiber, K. C., \& Peterson, P. L. (1988). Thinking skills versus learning time: Effects of alternative classroom-based interventions on students' mathematics problem solving. Cognition and Instruction, 5(2), 123-191. https://doi.org/10.1207/s1532690xci0502_2

Tanışlı, D. (2013). İlköğretim matematik öğretmeni adaylarının pedagojik alan bilgisi bağlamında sorgulama becerileri ve öğrenci bilgileri [Preservice primary school mathematics teachers' questioning skills and knowledge of students in terms of pedagogical content knowledge]. Education and Science, 38(169). http://egitimvebilim.ted.org.tr/index.php/EB/article/view/1736

Toluk-Uçar, Z. (2011). Öğretmen adaylarının pedagojik içerik bilgisi: Öğretimsel açıklamalar [Preservice teachers' pedagogical content knowledge: instructional explanations]. Turkish Journal of Computer and Mathematics Education, 2(2), 87-102. https://dergipark.org.tr/tr/pub/turkbilmat/ issue $/ 21564 / 231439$

Türnüklü, E. B., \& Yeşildere, S. (2005). Problem, problem solving and critical thinking. Gazi University Journal of Education, 25(3), 107-123. https://dergipark.org.tr/tr/pub/gefad/issue/6755/90828

Wilson, P. H., Mojica, G. F., \& Confrey, J. (2013). Learning trajectories in teacher education: Supporting teachers' understandings of students' mathematical thinking. Journal of Mathematical Behavior, 32(2), 103-121. https://doi.org/10.1016/j.jmathb.2012.12.003

Yavuz, G. (2006). The effect of problem solving strategy teaching on affective characteristics and access in ninth grade mathematics course [Unpublished doctoral dissertation], DEU Institute of Educational Sciences.

Yenmez, A. A., Erbas, A. K., Cakiroglu, E., Cetinkaya, B., \& Alacaci, C. (2017). Mathematics teachers' knowledge and skills about questioning in the context of modeling activities. Teacher Development, 22(4), 497-518. https://doi.org/10.1080/13664530.2017.1338198

Yıldırım, A., \& Şimsek, H. (2013). Sosyal bilimlerde nitel araştırma yöntemleri [Qualitative research methods in the social sciences]. Seckin Publishing. 
Yin, R. K. (2014). Case study methods: Design and methods (5th ed.). Sage Publishing.

Yüksek Öğretim Kurumu (YÖK). (2006). Eğitim fakültesi ögretmen yetiştirme lisans programı: sınıf ögretmenliği lisans programı ders içerikleri [Faculty of Education Teacher Training Undergraduate Program: Classroom Teaching Undergraduate Program Course Contents]. http://www.yok.gov.tr/ documents/10279/49665/sinif_ogretmenligi.pdf/32dd5579-2e4d-454e-8c91-5e0594ebdf48

Received: November 03, 2021

Accepted: January 24, 2022

$\mid$\begin{tabular}{l} 
PROBLEMS \\
OF EDUCATION \\
IN THE 21 $1^{\text {st }}$ CENTURY \\
Vol. 80, No. 1, 2022 \\
\hline 161
\end{tabular}

Cite as: Cumhur, F. (2022). Pre-service teachers' approaches to guiding students in problem solving process. Problems of Education in the $21^{s t}$ Century, 80(1), 144-161. https://doi.org/10.33225/pec/22.80.144

Fatma Cumhur

$\mathrm{PhD}$, Assistant Professor, Mathematics and Science Education Department, Muş Alparslan University, Diyarbakır Yolu 7. km, 49250 Merkez/Muş,

Turkey.

E-mail: cumhurfatma@gmail.com

ORCID: https://orcid.org/0000-0001-5891-564X 